\section{Effect of Chick Weight, Geometric Mean Diameter and Sodium Level In Prestarter Diets (1 to 7 Days) on Broiler Perfomance up to 21 Days of Age}

Author(s)

Ribeiro AML

Krabbe $E L^{2}$

Penz Júnior $\mathrm{AM}^{3}$

Renz SV ${ }^{4}$

Gomes $\mathrm{HA}^{4}$

UFRGS, Professor

Graduated student in Animal Science, UFRGS

3 UFRGS, Professor

4 Undergraduate students, UFRGS

\section{Mail Address}

Andréa Machado Leal Ribeiro UFRGS, Professor

Av. Bento Gonçalves, 7712

91.540-000 - Porto Alegre, RS, Brasil

E-mail: aribeiro@ufrgs.br

\section{Keywords}

average geometric diameter, broilers, initial weight, pre-starter diets, sodium.

\section{ABSTRACT}

Seven hundred and twenty Ross 308 chicks were raised in a controlled environment room, distributed in a factorial design with 3 hatching chick weights (37, 40 and $44 \mathrm{~g}), 3$ geometric mean diameter (GMD) (0.561; 0.783 and $0.997 \mathrm{~mm})$ and 4 total sodium levels $(\mathrm{Na})(0.12 ; 0.24 ; 0.36$ and $0.48 \%$ ) in the pre-starter diet (1 to 7 days). From 8 to 21 days (d) one single basal diet was used for all treatments. The thirty seven-gram chicks had the smallest yolk sack weight at $4 d$, smallest body weight (BW) and feed intake (FI) at $7 \mathrm{~d}$ and $21 \mathrm{~d}$, but the same feed conversion (FC) than the other groups of hatching weight. Chicks receiving diet with intermediate GMD had the greatest BW and FI at 7d, but at 21d this effect was no longer seen. The diet with finest particle size resulted in birds with the smallest gizzard weight at $7 d$. The $0.12 \% \mathrm{Na}$ diet was statistically different from the other $\mathrm{Na}$ levels, resulting in chicks at $7 d$ with the worst FC and lowest body weights. At $21 \mathrm{~d}$, BW still was the lowest for this group of chicks. Birds with $0.48 \% \mathrm{Na}$ produced more watery excreta and less dry matter in the carcass at $7 \mathrm{~d}$. Water consumption $\left(\mathrm{C}_{\mathrm{H} 2 \mathrm{O}}\right)$ was influenced linearly by chick weight up to $0.36 \% \mathrm{Na}$ level. In the $0.48 \% \mathrm{Na}$ level, 40 and $44 \mathrm{~g}$ chicks had similar $\mathrm{C}_{\mathrm{H} 2 \mathrm{O}}$, which was different from 37-g chicks. For best performance, $\mathrm{Na}$ values were set from 0.31 to $0.48 \%$. The three studied factors influenced quality of pre-starter diet and consequently chick performance.

\section{INTRODUCTION}

In the last 10 years, interest in early nutrition research has increased due to the high correlation between 7-d-old weight and final weight. This phase represents about $20 \%$ of the lifespan of broilers, when the highest growth rate takes place (Gonzalez \& Saldanha, 2001). Some reasons that justify the use of a different diet in the first week are the special characteristics of the digestive tract, related to anatomy and physiology, the limiting nutritional requirements due to the difficulty in absorbing certain nutrients, the potentially fast development of the first days of life and the great difficulty to guarantee survival in cold environments (Penz \& Vieira, 1998; Cromm et al., 1999).

Concerning mineral requirements, Borges et al. (2002) observed that sodium supplementation in the first week stimulated feed intake. Maiorka et al. (1998) have shown that an approximate value of $0.40 \%$ of sodium in the diet increased weight gain, feed and water intake, and resulted in better feed conversion in chicks. Similar results were found by Vieira et al. (2003), who estimated a range from 0.38 to $0.40 \%$ of sodium requirements for this phase. However, the positive effects of sodium high levels were not seen at $42 \mathrm{~d}$ of age. In that work, the increment of diet electrolyte balance from 160 to $240 \mathrm{mEq} / \mathrm{kg}$ improved weight gain and feed conversion only during the first $4 \mathrm{~d}$. Although 

Júnior AM, Renz SV, Gomes HA
Ribeiro AM, Krabbe EL, Penz

Maiorka et al. (1998) and Borges et al. (1999) reported no increase in litter humidity, this parameter should be assessed when sodium increments are evaluated.

Diet particle size may influence feed intake and ingredient digestion by changes on gastrointestinal tract anatomy and on digestive secretions. Nir et al. (1990) concluded that young birds consumed feed in accordance to its coarseness when free choice was available. Ribeiro et al. (2002) observed that birds between 21 and 42 days had better performance when fed corn with $0.87 \mathrm{~mm}$ of geometric mean diameter (GMD). Dahlke et al. (2001) noticed that a very fine corn $(0.336 \mathrm{~mm}$ of GMD) was less harmful when included in pellet diets, and corn with GMD up to $1.12 \mathrm{~mm}$ did not decrease broilers performance from 21 to 42 days of age. Nir (1997) found a significant correlation between body weight in the first and second weeks and the final weight (42 days). According to the authors, each gram of initial weight corresponds to 5 to 8 grams at the $6^{\text {th }}$ week. Pedrozzo et al. (2000) observed $51 \%$ of correlation between initial weight (first day) and weight at $42 \mathrm{~d}$ of age. The study described in this paper aimed to determine the best sodium level and GMD in pre-starter diets, as well to evaluate the effect of chick initial weight on performance of 21 days old broilers. Water consumption, excreta dry matter and carcass dry matter were also analyzed.

\section{MATERIAL AND METHODS}

Seven hundred and twenty Ross 308 chicks were divided in 36 treatments according to a factorial design with 3 initial chick weights (IW) $(37 ; 40$ and 44 g), 3 GMD diets $(0.561 ; 0.783$ and $0.997 \mathrm{~mm})$ and 4 total sodium levels $(0.12 ; 0.24 ; 0.36$ and $0.48 \%)$, in the prestarter diets ( 1 to 7 days). The experiment was conducted in batteries with 10 birds per cage, and a total of 72 experimental units (EU). For each treatment, there were 2 replicates. Diet compositions were similar, except for the sodium levels. Sodium bicarbonate was used to keep a diet electrolyte balance among $\mathrm{Na}, \mathrm{Cl}$ and $\mathrm{K}$ of $160 \mathrm{mEq} / \mathrm{kg}$ (Table 1). Corn was ground using a hammer mill with different sieves $(2,8$ and $10 \mathrm{~mm})$ to achieve the different GMD values. From 8 to 21 days, one single diet was used for all treatments and levels were $2,950 \mathrm{kcal} \mathrm{ME} / \mathrm{kg} ; 21.1 \% \mathrm{CP} ; 1.05 \% \mathrm{Ca}$; $0.45 \%$ Avail $P ; 0.32 \% \mathrm{Na} ; 1.12 \%$ dig. Lys; $0.95 \%$ dig Met+Cys and $0.459 \mathrm{~mm}$ GMD. Feed intake (FI), weight gain (WG) and body weight (BW) were evaluated and feed conversion (FC) was estimated at 7 and 21 days.
Effect of Chick Weight, Geometric Mean Diameter and Sodium Level In Prestarter Diets (1 to 7 Days) on Broiler Perfomance up to 21 Days of Age
At the age of $4 d$, one bird/EU was sacrificed to determine the weight of the residual yolk sac. At 7 days, one bird/EU was sacrificed according to EU mean body weight to measure gizzard weight and carcass dry matter (AOAC, 1984). The same procedure was repeated at 21 days for gizzard weight. Water consumption from 1 to 7 days was evaluated based on the difference among drinker weight in a 24-hour interval. From 4 to 7 days, excreta dry matter (DM) was determined.

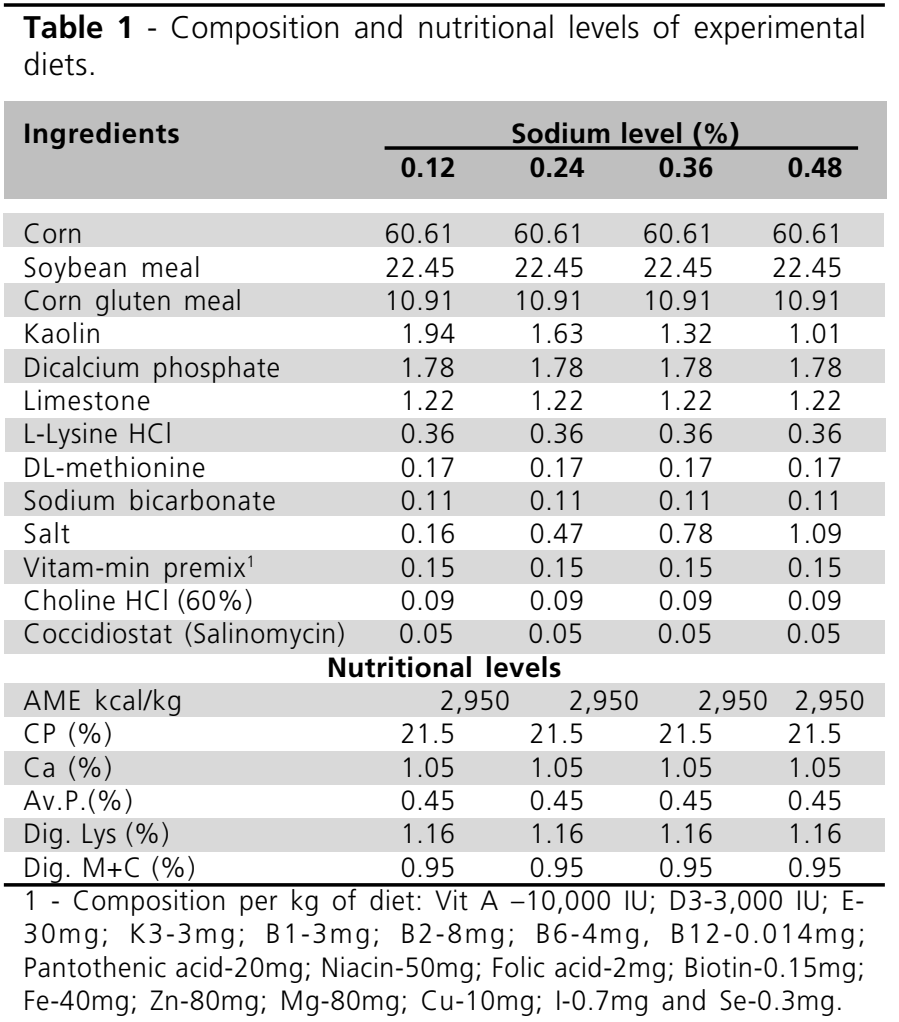

Data analysis was carried out by response surface analysis: when IW was analyzed by regression analysis, all treatments with the same IW were considered, independent of AGD and sodium level. For each IW level, there were 24 replications. The same was considered for GMD. For each sodium level, 18 replicates were considered. All variables were submitted to analysis of variance and regression analysis. Statistical analysis was performed using the software SAS (1986) and the means were compared by Tukey's test $(p<0.05)$.

\section{RESULTS AND DISCUSSION}

Body weight, weight gain, feed intake and feed conversion at the age of 7 and 21 days. 
Ribeiro AM, Krabbe EL, Penz Júnior AM, Renz SV, Gomes HA
All the observed results will be analyzed by the residual effect of the diet fed in the first week, since the birds were given one single diet after the $8^{\text {th }}$ day. Interactions among the three factors were not significant $(p>0.05)$. Consequently, when the main effects were observed, chick initial weight positively influenced body weight at 7 days. Lighter chicks presented lower WG and FI than the others, but FC was better compared to the intermediate group $(p<0.05)$ (Table 2). Diet GMD affected BW, WG and $\mathrm{FI}$ significantly. Better performance was observed for intermediate GMD $(0.783 \mathrm{~mm})$. This variable did not influence FC. Nir.(1997) observed that 4 dayold chicks were already capable to distinguish small differences in particle size. They also reported that $0.88 \mathrm{~mm}$ GMD diets were more consumed than 0.7 and $0.5 \mathrm{~mm}$ diets. The present work indicated a maximum GMD limit for the first week of life; particles higher than $0.80 \mathrm{~mm}$ may negatively influence bird feed intake. The total sodium level of $0.12 \%$ negatively affected BW and WG $(p<0.001)$; other sodium levels did not affect performance ( $p>0.05)$. Feed intake showed a curvilinear response, increasing up to $0.36 \% \mathrm{Na}$ and then declining at $0.48 \% \mathrm{Na}$. There was a linear improvement in FC with increasing sodium levels.

The regression analysis for $\mathrm{FI}$ and FC showed that the best equation included all studied factors. Only sodium level was significant for WG, whereas for BW
Effect of Chick Weight, Geometric Mean Diameter and Sodium Level In Prestarter Diets (1 to 7 Days) on Broiler Perfomance up to 21 Days of Age either sodium level or GMD were significant. The maximum response for BW was obtained with $0.37 \%$ $\mathrm{Na}$ and $0.791 \mathrm{~mm}$ of $\mathrm{AGD}$. The maximum WG was obtained with $0.37 \% \mathrm{Na}$. The best levels for $\mathrm{Fl}$ were $43 \mathrm{~g}$ of IW, $0.794 \mathrm{~mm}$ of $\mathrm{AGD}$ and $0.31 \% \mathrm{Na}$, whereas for FC the levels were $38.3 \mathrm{~g}$ of IW, $0.788 \mathrm{~mm}$ of GMD and $0.48 \%$ of sodium. Higher sodium levels in pre-starter diets have been previously reported to stimulate $\mathrm{FI}$ (Borges et al., 2002).

During the period from 1 to 21 days there were no significant interactions ( $p>0.05$ ) among the studied factors. Light chicks (37g) still had significant less BW, WG and $\mathrm{FI}$ at $21 \mathrm{~d}$ compared to the intermediate or heavy chicks $(p<0.001)$ (Table 3$)$. Initial weight, on the other hand, did not influence FC ( $p>0.05)$. The pre-starter diet with GMD of $0.997 \mathrm{~mm}$ still had negative effects on the Fl of 21 day-old chicks, when compared to the intermediate particle size $(p<0.02)$. Nevertheless, GMD did not influence the other variables. At 21 days, a sodium effect on BW and WG remained; birds receiving $0.48 \% \mathrm{Na}$ in prestarter diet had greater BW and WG than chicks fed with a $0.12 \%$ sodium diet $(p<0.03)$. None of the factors affected FC significantly at 21 days on the regression analysis. Maximum response for BW was obtained with $0.40 \% \mathrm{Na}$ and $42 \mathrm{~g}$ of IW. Maximum WG was obtained with $42 \mathrm{~g}$ IW chicks. GMD and IW influenced feed intake and maximum Fl were obtained with IW and AGD of $42 \mathrm{~g}$ and $0.754 \mathrm{~mm}$, respectively.

Table 2 - Effect of chick weight (IW), geometric mean diameter (GMD) and total sodium level in the diet on body weight (BW), weight gain (WG), feed intake (FI) and feed conversion (FC) of broilers at 7 days of age.

\begin{tabular}{|c|c|c|c|c|c|c|}
\hline IW (g) & GMD (mm) & Sodium (\%) & BW (g) & WG (g) & $\mathrm{FI}(\mathrm{g})$ & $F C(g / g)$ \\
\hline 37 & & & $143 c$ & $105 b$ & $131 \mathrm{~b}$ & $1.26 \mathrm{~b}$ \\
\hline 40 & & & $153 \mathrm{~b}$ & $113 a$ & $146 a$ & $1.30 \mathrm{a}$ \\
\hline 44 & & & $161 \mathrm{a}$ & $117 a$ & $150 a$ & $1.29 a b$ \\
\hline & 0.561 & & $149 \mathrm{~b}$ & $108 \mathrm{~b}$ & $139 \mathrm{~b}$ & 1.29 \\
\hline & 0.783 & & 159 a & $118 a$ & 148 a & 1.26 \\
\hline & 0.997 & & $150 \mathrm{~b}$ & $109 \mathrm{~b}$ & $140 \mathrm{~b}$ & 1.29 \\
\hline & & 0.12 & $137 \mathrm{~b}$ & $96 \mathrm{~b}$ & $138 \mathrm{~b}$ & $1.43 \mathrm{a}$ \\
\hline & & 0.24 & $156 a$ & $115 \mathrm{a}$ & $145 a b$ & $1.26 \mathrm{~b}$ \\
\hline & & 0.36 & $160 \mathrm{a}$ & $119 a$ & $147 a$ & $1.23 \mathrm{bc}$ \\
\hline \multicolumn{7}{|c|}{$\begin{array}{l}157 \text { a } \\
\text { Probabilities }\end{array}$} \\
\hline IW & & & 0.001 & 0.001 & 0.001 & 0.01 \\
\hline AGD & & & 0.001 & 0.001 & 0.01 & 0.18 \\
\hline Sodium & & & 0.001 & 0.001 & 0.03 & 0.001 \\
\hline \multicolumn{7}{|c|}{ Regression analysis } \\
\hline Variable & Equation & & & & $P$ & $R^{2}$ \\
\hline $\mathrm{BW}(\mathrm{g})$ & \multicolumn{4}{|c|}{$Y=-5.08+0.31 \mathrm{GMD}+273 \mathrm{Na}-0.0002 \mathrm{GMD}^{2}-368 \mathrm{Na}^{2}$} & 0.0000 & 0.46 \\
\hline WG (g) & \multicolumn{4}{|c|}{$\mathrm{Y}=68.73+277.9 \mathrm{Na}-374 \mathrm{Na}^{2}$} & 0.0000 & 0.43 \\
\hline $\mathrm{FI}(\mathrm{g})$ & \multicolumn{4}{|c|}{$Y=-932.9+43.9 \mathrm{IW}+0.30 \mathrm{GMD}+160 \mathrm{Na}-0.51 \mathrm{IW}^{2}-0.0002 \mathrm{GMD}^{2}-256 \mathrm{Na}^{2}$} & 0.0000 & 0.49 \\
\hline $\mathrm{FC}(\mathrm{g} / \mathrm{g})$ & \multicolumn{4}{|c|}{$Y=-2.80+0.23 \mathrm{IW}-0.0009 \mathrm{GMD}-1.99 \mathrm{Na}-0.003 \mathrm{IW}^{2}-0.0000 \mathrm{GMD}^{2}+2 \mathrm{Na}^{2}$} & 0.0000 & 0.73 \\
\hline
\end{tabular}

abc - Means followed by different letters are different $(p<0.05)$ by Tukey's test. 
Table 3 - Effect of chick weight (IW), geometric mena diameter (GMD) and total sodium level in the diet on body weight (BW), weight gain (WG), feed intake (FI) and feed conversion (FC) of broilers at 21 days of age.

\begin{tabular}{|c|c|c|c|c|c|c|}
\hline IW (g) & GMD (mm) & Sodium (\%) & BW (g) & WG (g) & FI (g) & $\mathrm{FC}(\mathrm{g} / \mathrm{g})$ \\
\hline 37 & & & $779 \mathrm{~b}$ & $741 \mathrm{~b}$ & $1,080 \mathrm{~b}$ & 1.46 \\
\hline 40 & & & $817 a$ & $766 a$ & 1,132 a & 1.46 \\
\hline 44 & & & $819 a$ & $755 \mathrm{a}$ & $1,137 a$ & 1.47 \\
\hline & 0.561 & & 812 & 771 & $1,113 a b$ & 1.44 \\
\hline & 0.783 & & 808 & 767 & 1,143 a & 1.49 \\
\hline & 0.997 & & 795 & 754 & $1,092 b$ & 1.45 \\
\hline & & 0.12 & $781 \mathrm{~b}$ & $740 \mathrm{~b}$ & 1,093 & 1.48 \\
\hline & & 0.24 & $812 a b$ & $772 a b$ & 1,123 & 1.46 \\
\hline & & 0.36 & $810 a b$ & $769 a b$ & 1,132 & 1.47 \\
\hline & & 0.48 & $817 a$ & $776 a$ & 1,115 & 1.44 \\
\hline \multicolumn{7}{|c|}{ Probabilities } \\
\hline IW & 0.001 & 0.004 & 0.002 & 0.97 & & \\
\hline AGD & 0.30 & 0.30 & 0.02 & 0.06 & & \\
\hline Sodium & 0.03 & 0.03 & 0.31 & 0.40 & & \\
\hline \multicolumn{7}{|c|}{ Regression analysis } \\
\hline Variable & \multicolumn{4}{|c|}{ Equation } & $\mathbf{P}$ & $\mathbf{R}^{2}$ \\
\hline BW & \multicolumn{4}{|c|}{$Y=-2373+148 \mathrm{IW}+339 \mathrm{Na}-1.75 \mathrm{IW}^{2}-0.04 \mathrm{Na}^{2}$} & 0.0003 & 0.27 \\
\hline WG $(g)$ & \multicolumn{4}{|c|}{$Y=-2388+149 \mathrm{IW}+89.45 \mathrm{Na}-1.77 \mathrm{IW}^{2}$} & 0.0007 & 0.22 \\
\hline $\mathrm{FI}(\mathrm{g})$ & \multicolumn{4}{|c|}{$Y=-3491+196 \mathrm{IW}+1.28 \mathrm{GMD}-2.31 \mathrm{IW}^{2}-0.0008 \mathrm{GMD}^{2}$} & 0.0003 & 0.27 \\
\hline
\end{tabular}

abc - Means followed by different letters are different $(\mathrm{p}<0.05)$ by Tukey's test.

\section{Yolk sac weight at 4 days and gizzard weight at 7 days}

Thirty seven-gram chicks had smaller yolk sac at 4 days than 40 and $44 \mathrm{~g}$ chicks $(p<0.02)$. The other factors did not affect this variable (Table 4). The importance of yolk sac on the transition between embrionary life and hatch life is well known. Murakami et al.(1988) stated that the nutrients found in this structure represent $50 \%$ of the energy and $43 \%$ of the protein required by the chick at its first day of life, whereas Dibner et al.(1998) argued that the protein and lipid fractions of the yolk sac are probably more used for cell membrane synthesis and to the maintenance of passive immunity than for fulfilling energy requirements. Noy \& Sklan (1999) verified that even fasted chicks had $80 \%$ of increment in the intestine weight and in its protein content during the first 48 hours after hatch. The authors stated that this increment resulted mostly from the yolk sac nutritional reserves. The findings suggest that larger chicks have higher probability of surviving due to heavier yolk sacs.

At 7 days of age it was possible to observe an effect of GMD on gizzard weight. Gizzard was significantly heavier in chicks receiving 0.997 and $0.783-\mathrm{mm}$ diets $(p<0.001)$. Similar results have been reported for 42 day-old broilers (Ribeiro et al., 2002). The other factors did not influence gizzard weight at 7 and 21 days. Besides, GMD was no longer significant at 21 days. Ribeiro et al.(2002) reported that gizzard weight in 42 day-old broilers was correlated positively with particle size increments, within the range between 0.337 and $0.936 \mathrm{~mm}$.

\footnotetext{
Table 4 - Effect of chick weight (IW), geometric mean diameter (GMD) and total sodium level in the diet on the yolk sac weight (YSW) at 4 days and relative gizzard weight (RGW) at 7 days of age.
}

\begin{tabular}{|c|c|c|c|c|}
\hline IW (g) & GMD $(\mathrm{mm})$ & Sodium (\%) & YSW (g) & RGW (g/100g) \\
\hline 37 & & & $0.26 \mathrm{~b}$ & 4.43 \\
\hline 40 & & & $0.54 \mathrm{a}$ & 4.47 \\
\hline 44 & & & $0.55 \mathrm{a}$ & 4.58 \\
\hline & 0.561 & & 0.48 & $4.07 \mathrm{~b}$ \\
\hline & 0.783 & & 0.51 & $4.71 \mathrm{a}$ \\
\hline & 0.997 & & 0.37 & $4.70 \mathrm{a}$ \\
\hline & & 0.12 & 0.63 & 4.57 \\
\hline & & 0.24 & 0.41 & 4.35 \\
\hline & & 0.36 & 0.37 & 4.47 \\
\hline & & 0.48 & 0.40 & 4.59 \\
\hline \multicolumn{5}{|c|}{ Probabilities } \\
\hline IW & & & 0.02 & 0.60 \\
\hline AGD & & & 0.49 & 0.001 \\
\hline Sodium & ר & + & 0.19 & 0.51 \\
\hline
\end{tabular}

\section{Water consumption}

There was a significant interaction between initial weight and sodium level $(p<0.001)$ related to water consumption (Table 5). Water consumption increased linearly with chick initial weight up to $0.36 \%$ of sodium. Nevertheless, water consumption was significantly lower $(p<0.05)$ when sodium level was $0.48 \%$ only for 
Table 5 - Effect of chick weight (IW), geometric mean diameter (GMD) and total sodium level in the diet on water consumption from 1 to 7 days of age.

\begin{tabular}{|c|c|c|c|c|}
\hline $\begin{array}{l}\text { IW } \\
(g)\end{array}$ & $\begin{array}{l}\text { GMD } \\
(\mathrm{mm})\end{array}$ & $\begin{array}{l}\text { Sodium } \\
(\%)\end{array}$ & \multicolumn{2}{|c|}{$\begin{array}{l}\text { Water consumption } \\
(\mathrm{mL} / \mathrm{bird})\end{array}$} \\
\hline 37 & & & \multicolumn{2}{|r|}{298} \\
\hline 40 & & & \multicolumn{2}{|r|}{332} \\
\hline 44 & & & \multicolumn{2}{|r|}{363} \\
\hline & 0.561 & & \multicolumn{2}{|c|}{$330 a b$} \\
\hline & 0.783 & & \multicolumn{2}{|r|}{348 a } \\
\hline & 0.997 & & \multicolumn{2}{|r|}{$314 b$} \\
\hline & & 0.12 & \multicolumn{2}{|r|}{312} \\
\hline & & 0.24 & \multicolumn{2}{|r|}{319} \\
\hline & & 0.36 & \multicolumn{2}{|r|}{332} \\
\hline & & 0.48 & \multicolumn{2}{|r|}{359} \\
\hline \multicolumn{5}{|c|}{ Interaction IW x Sodium (mL/bird) } \\
\hline IW & $0.12 \% \mathrm{Na}$ & $0.24 \% \mathrm{Na}$ & $0.36 \% \mathrm{Na}$ & $0.48 \% \mathrm{Na}$ \\
\hline $37 g$ & $266 a A$ & $285 \mathrm{aA}$ & $295 a A$ & $345 a B$ \\
\hline $40 \mathrm{~g}$ & $302 \mathrm{bA}$ & $321 \mathrm{bA}$ & $337 b A B$ & $367 \mathrm{bB}$ \\
\hline $44 \mathrm{~g}$ & $369 c A$ & $352 c A$ & $365 c \mathrm{~A}$ & $365 \mathrm{bA}$ \\
\hline \multicolumn{5}{|c|}{ Probabilities } \\
\hline & IW & & & 0.01 \\
\hline \multicolumn{3}{|c|}{ GMD } & & 0.02 \\
\hline \multicolumn{3}{|c|}{ Sodium } & & 0.005 \\
\hline \multicolumn{3}{|c|}{ Interaction IW x Sodium } & & 0.001 \\
\hline \multicolumn{5}{|c|}{$\begin{array}{l}\text { abc - Means followed by different small letters in the column are } \\
\text { different }(p<0.05) \text { by Tukey's test. } A B C-M e a n s \text { followed by different } \\
\text { capital letters in the row are different }(p<0.05) \text { by Tukey's test. }\end{array}$} \\
\hline
\end{tabular}

37-g chicks. In other words, chick initial weight is a main variable when water consumption is considered based on the usual sodium levels in chick diets. Small chicks are more predisposed to dehydration due to management mistakes and should be observed more closely. Leeson \& Summers (2001) affirmed that with the advent of nipple drinkers in commercial production, it became evident that birds were unwilling or unable to consume normal intakes of water. Consequently, the increment in diet sodium levels is an alternative to improve water consumption. On the other hand, 37 and 40-g birds increased water consumption at the higher sodium levels, whereas water consumption was not affected in 44-g birds by sodium increments. Besides, water and feed intakes were similarly affected by GMD, showing that they are closely related. Viola et al.(in press) observed reductions of $9.6 \mathrm{~g}$ and $8.5 \mathrm{~g}$ per bird in feed intake and weight gain, respectively, for each percent of water reduction imposed to broilers from 1 to 21 days of age.

\section{Carcass and excreta dry matter}

Carcass dry matter of 7-day-old chicks was significantly influenced by sodium level $(p<0.03)$. The diet with $0.48 \%$ Na resulted in lower carcass dry matter than the diets with 0.12 and $0.24 \% \mathrm{Na}$. On the other hand, no differences ( $p>0.05$ ) were observed compared to $0.36 \%$ Na diet $(21.6 ; 21.7 ; 21.0$ and $20.4 \%$ DM for levels of $0.12 ; 0.24 ; 0.36$ and $0.48 \% \mathrm{Na}$ ). Only the highest level of sodium $(0.48 \%)$ affected excreta DM significantly $(p<0.05)$, which was decreased $(22 \%$ DM at $0.48 \%$ and $25 \%$ DM at other levels). Sodium levels from 0.12 to $0.36 \%$ did not affect excreta humidity $(p>0.05)$. These results are very important in practical conditions, because pre-starter diets comprise higher levels of sodium. Leeson \& Summers (2001) reported a linear relationship between early growth rate and total sodium in the diet, and the maximum level to be used is usually dictated by manure consistency. Additionally, heavier chicks in the present study produced more liquid excreta $(25.5 ; 24.7 ; 23.1$ for 37,40 and $44-9$ chicks, respectively). This fact could be explained by the higher water consumption that heavier chicks presented, as mentioned above (Table 5). Borges et al.(1999) showed that diets containing 0.30 and $0.45 \%$ of sodium did not increase litter humidity when compared to commercial diets.

\section{CONCLUSIONS}

The results suggest that broilers respond to prestarter diets with different sodium levels or GMD and these variables can significantly affect performance results of 7-day-old chicks and also have impact on the performance at 21 days of age. From 1 to 7 days of age, either higher levels of sodium or GMD around $0.75 \mathrm{~mm}$ can stimulate feed intake. Initial chick weight influences body weight at 21 days of age.

\section{REFERENCES}

AOAC. ASSOCIATION OF OFFICIAL ANALITICAL CHEMISTS. Official methods of analysis. $12^{\text {nd }}$ ed. Washington, D.C., 1984. 1094p.

Borges AS, Ariki J, Santin E, Fisher da Silva AV, Maiorka A. Balanço eletrolítico em dieta pré-inicial de frangos de corte durante o verão. Revista Brasileira de Ciência Avícola 1999; 1:175-179.

Borges AS, Maiorka A, Laurentiz AC, Fisher da Silva AV, Santin E, Ariki J. Eletrolyte balance in broiler chicks during the first week of age. Revista Brasileira de Ciência Avícola 2002; 4(2):149-153.

Cromm WJ, Brake J, Coles BA et al.Is intestinal absorption capacity rate-limiting for performance in poultry? Journal of Applied Poultry Research 1999; 8:242-252.

Dahlke F, Ribeiro AML, Kessler AM, Lima AR. Tamanho da partícula do milho e forma física da ração e seus efeitos sobre o desempenho e rendimento de carcaça de frangos de corte. Revista Brasileira de Ciência Avícola 2001; 3(3):241-248. 
Dibner JJ, Knight CD, Kitchell ML, Atwell CA, Downs AC, Ivey FJ. Early feeding and development of the immune system in neonatal poultry. Journal of Applied Poultry Research 1998; 7:425-436.

Gonzalez E, Saldanha ESPB. Os primeiros dias de vida do frango e a produtividade futura. 2001 . In: $2^{\circ}$ Congresso Brasileiro de Zootecnia, ZOOTEC I; 2001; Goiania, Goiás. Brasil. p.310-327.

Leeson S, Summers JD. Scott's nutrition of the chicken. $4^{\text {th }}$ ed. Guelph, Ontario: Chemistry of Books, 2001. 591p.

Maiorka A, Magro N, Bartels HA, Penz Jr AM. Efeito do nível de sódio e diferentes relações entre sódio, potássio e cloro em dietas pré-iniciais no desempenho de frangos de corte. In: Reunião Anual da Sociedade Brasileira de Zootecnia; 1998 julho 27-31; Botucatu, São Paulo. Brasil. Botucatu: Sociedade Brasileira de Zootecnia; 1998. v.1, p.478-480.

Murakami H, Akiba Y, Horiguchi M. Energy and protein utilisation in newly-hatched broiler chicks: studies on the early nutrition of poultry. Japanese Journal of Zootechnical Science 1988; 59:890895.

Nir I, Melcion JP, Picard M. Effect of particle size of sorghum grains on feed intake and performance by young broilers. Poultry Science $1990 ; 69: 2177-2184$

Nir I. Optimization of early growth in fast-growing broilers: nutrition and physiological aspects. In: Jornada Internacional de Avicultura de Carne; 1997; Madri. Espanha. v.6, p:1-10.

Noy Y, Sklan D. Energy utilization in newly hatched chicks. Poultry Science 1999; 78(12):1750-1756.

Pedrozzo S, Penz Jr AM, Ribeiro AML. Relatório Técnico Efeito de probiótico e peso de pinto no desempenho, rendimento de carcaça e micrometria de intestino delgado de frangos de corte de 1 a 42 dias de idade. Porto Alegre: Faculdade da Agronomia, Universidade Federal do Rio Grande do Sul; 2000.

Penz Jr AM, Vieira SL. Nutrição na Primeira Semana. In: Conferência Apinco de Ciência e Tecnologia Avícolas; 1998; Campinas, São Paulo, Brasil. Campinas: FACTA; 1998. p.121-139.

Ribeiro AML, Magro N, Penz Jr AM. Granulometria do milho em rações de crescimento de frangos de corte e seu efeito no desempenho e metabolismo. Revista Brasileira de Ciência Avícola 2002; 4(1):47-54.

SAS. SAS/STAT ${ }^{\text {TM }}$ Guide for personal computers, Version $6^{\text {th }}$ edition. Cary, NC: SAS Institute; 1986.

Vieira SL, Penz, Jr AM, Pophal S, Godoy de Almeida J. Sodium requirements for the first seven days in broiler chicks. Journal of Applied Poultry Research 2003; 12:362-370.

Viola T, Penz Jr AMP, Ribeiro AML. A influência da restrição da água no desempenho e no desenvolvimento de órgãos de frangos de corte de 1 a 21 dias de idade. Local: Editora. No prelo. 